\title{
Teaching Specialized Legal Research: Business Associations
}

Kris Helge

Terri Lynn Helge

Texas A\&M University School of Law, thelge@law.tamu.edu

Follow this and additional works at: https://scholarship.law.tamu.edu/facscholar

Part of the Business Organizations Law Commons, and the Legal Education Commons

\section{Recommended Citation}

Kris Helge \& Terri L. Helge, Teaching Specialized Legal Research: Business Associations, 29 Legal Reference Serv. Q. 51 (2010).

Available at: https://scholarship.law.tamu.edu/facscholar/1079

This Article is brought to you for free and open access by Texas A\&M Law Scholarship. It has been accepted for inclusion in Faculty Scholarship by an authorized administrator of Texas A\&M Law Scholarship. For more information, please contact aretteen@law.tamu.edu. 


\title{
Teaching Specialized Legal Research: Business Associations
}

\author{
KRIS HELGE and TERRI LYNN HELGE \\ Texas Wesleyan University School of Law, Ft. Worth, Texas, USA
}

\begin{abstract}
Business associations are a complex substantive topic that can be included in an advanced legal research course that teaches students sophisticated research, writing, and citation skills. This article presents the basic substantive law regarding business associations necessary to deliver instruction about advanced legal research, writing, and citation. This article also offers a model syllabus with suggested sources and assignments for students. These research assignments require students to perform tasks such as citing primary and secondary sources, learning advanced research skills using loose-leaf materials, assimilating information from multiple sources into cogent narratives, locating information using various electronic resources, digests, and other secondary sources, and locating and using forms pertinent to business association agreements. This article also provides an instructor with twenty-five suggested sources to use in assigning materials to students. These sources consist of both print and electronic versions. They additionally consist of treatises, monographs, guides, model statutory materials, electronic databases, Web sites, form guides, casebooks, a digest, and a citation manual.
\end{abstract}

KEYWORDS associations, bibliography, business, sources, substantive, syllabus

The authors would like to gratefully acknowledge Mark Burge, Neal Newman, and George Butterfield for their helpful comments on earlier drafts of this article.

Address correspondence to Kris Helge, 1216 Belle Meade Way, Burleson, TX. E-mail: kris834120@gmail.com 


\section{INTRODUCTION}

Business associations is a complex substantive topic that can be included in an advanced legal research course teaching students sophisticated research, writing, and citation skills. The purpose of this article is to provide a resource for instructors who are preparing an advanced legal research course focusing on business associations. The first part provides an overview of the state law and federal tax law governing business associations. Because the law of business associations is vast and contains many nuances, the first part also provides a brief background on certain aspects of business association law that typically comprise advanced legal research assignments. The second part supplies a model syllabus for a two-credit hour course that focuses on advanced legal research for business associations. The third part is an annotated bibliography of sources that may be used in conducting legal research related to business associations. It also contains sample research assignments.

\section{RELEVANT LAW TO TEACH A SPECIALIZED LEGAL RESEARCH CLASS PERTAINING TO BUSINESS ASSOCIATIONS}

\section{Overview of the Law Governing Business Associations}

Overview of the Forms of Business Associations

Business association is a term that refers to the device through which businesses are conducted. The most basic form is the sole proprietorship. In a sole proprietorship, the individual proprietor and the business are essentially the same for tax and legal liability purposes. The protections and formalities associated with other forms of business associations do not exist in a sole proprietorship.

A second form of business association is the general partnership, similar to a sole proprietorship but with two or more co-owners. ${ }^{1}$ The partners conduct the management of a general partnership, and generally, each is jointly and severally liable for business liabilities. ${ }^{2}$ Creditors may pursue one or more of the partners for amounts owed regardless of the partners' proportional interests. ${ }^{3}$ For tax purposes, the income of the partnership is taxed to the partners in proportion to their ownership interests in the partnership. ${ }^{4}$ This is known as "pass-through" taxation.

The remaining forms of business associations provide owners some legal liability protection. These forms include a corporation, a limited partnership (LP), a limited liability partnership (LLP), and a limited liability company (LLC) ${ }^{5}$ In each, creditors are restricted to collecting business debts out of business assets, and owners' personal assets are normally protected.

The corporation is the most common form of business association for large businesses. ${ }^{6}$ The corporation's owners, known as stockholders or 
shareholders, invest capital in the business in exchange for ownership interests represented by shares of stock in the corporation. A stockholder's shares entitle him or her to distributions of profits and the right to vote on certain major events of the corporation. ${ }^{7}$ The right to vote also includes the right to elect the directors who are charged with setting the corporate policies and overseeing the management of the corporation. ${ }^{8}$ The directors in turn select the officers who are charged with the day-to-day management of the corporation's operations. Shareholders' personal assets are protected from creditor's claims against the corporation. This means ${ }^{9}$ a stockholder's potential loss is limited to capital contributed. Corporations are taxed as separate entities ${ }^{10}$ and distributions of profits are taxed to the stockholders as dividend income. ${ }^{11}$

LPS, LLPS, and LLCS are hybrid forms of business associations. Like corporations, they typically provide legal liability protection for the owners; however, owners are taxed in proportion to their ownership interests. An LP is a partnership with both general and limited partners. ${ }^{12}$ A general partner manages the business and assumes unlimited liability for business liabilities. ${ }^{13}$ Limited partners are similar to corporation stockholders: they typically have voting rights on major organizational decisions (e.g., changes to the partnership agreement, dissolution of the partnership, merger of the partnership with another entity, or the sale of substantially all of the partnership's assets). ${ }^{14}$ They do not, however, participate in day-to-day management of the business. Limited partners may also be entitled to vote on the removal or replacement of a general partner. ${ }^{15}$ Also, like a corporate stockholder, a limited partner is normally legally liable only for the amount of capital contributed to the LP. ${ }^{16}$

LLPs and LLCs are similar types of business organizations. In both, the owners of the business (partners in LLPs and members in LLCs) may manage the day-to-day affairs of the business. In the context of an LLC, this is known as a member-managed LLC. ${ }^{17}$ LLC members may instead elect to have one or more managers manage the day-to-day business affairs. In this event, the members have the right to vote to select and remove the LLC managers. ${ }^{18}$ In addition, for both the LLP and the LLC, the partners or members are legally liable only for the amount of capital liable only for the amount of capital they contributed to the entity. ${ }^{19}$ Absent special circumstances, a creditor of an LLP or LLC may not satisfy its claims from the personal assets of the individual partners or members.

The business form affects many aspects of the operations of the business, including the manner in which the business association is formed, the liability protection afforded to the business owners, the rights of the business owners vis-à-vis the managers of the business, the manner in which capital for the business is raised and distributions of business profits to the owners occurs, and the taxation of the income from the business. These considerations are discussed in more detail in subsequent sections. 
FORMATION OF BuSINESS ASSOCIATIONS

Each type of business association has specific formation requirements. To protect the owners from personal liability, it is important they follow the formal formation requirements. When a business venture fails, creditors often assert claims that the business association was not properly formed, and its owners are therefore personally liable for company debts.

Partnerships. No particular formalities are required to form a general partnership, and it may be formed without any sort of filing with a government authority. ${ }^{20}$ The general partnership is the default form of business association created when two or more owners who do not take the necessary legal action to create another form of business association conduct business. ${ }^{21}$ As a result, owners of a business may form a general partnership without intending to do so and without knowing they have done so. The consequences of forming such an "inadvertent general partnership" are the same as the intentional formation of a general partnership, ${ }^{22}$ and include joint and several liability of the individual partners for the liabilities incurred in conducting the partnership business. ${ }^{23}$ Once a general partnership has been created, state partnership statutes, based on the Uniform Partnership $\mathrm{Act}^{24}$ or the Revised Uniform Partnership Act (RUPA), ${ }^{25}$ provide a set of default rules over the operation of the partnership. The partners may vary these default rules by written partnership agreement governing the internal rights and obligations of the partnership and its partners. ${ }^{26}$

To form an LLP, a certificate of LP, or its equivalent must be filed with the state's Office of the Secretary of State. ${ }^{27}$ The certificate is executed by the general partners ${ }^{28}$ and typically contains the name of the LP, the names and addresses of the general partners, and the name and address of the registered agent of the LP. ${ }^{29}$ Once the LP is formed, state partnership statutes based on the Revised Uniform Limited Partnership Act (RULPA) ${ }^{30}$ provide a set of default rules under which the LP is to be operated. The partners may vary the default rules governing internal rights and obligations of the LP and its partners by a written LP agreement. ${ }^{31}$ The LP agreement typically sets forth voting rights of the limited partners, allocation of profits and losses among the partners, provisions regarding contributions and distributions, procedures for withdrawal or removal of general and limited partners, procedures for admission of new general and limited partners, restrictions on transferability of partnership interests, and the manner and process for the dissolution of the LP.

An LLP is also formed by filing the requisite certificate with the appropriate state official and paying the required fee. ${ }^{32}$ Although the actual content varies by jurisdiction, the certificate includes the name of the LLP, the name and address of the registered agent, and a statement that the partnership elects to be an LLP. ${ }^{33}$ Some jurisdictions also have a minimum capital requirement or a minimum liability insurance coverage requirement. ${ }^{34}$ Some states may also require LLPs to file an annual return and pay an annual fee to 
maintain the limited liability protection for its partners. ${ }^{35}$ The authorization for LLPs is generally found in the states' general partnership statutes because LLPs are a type of general partnership, one that provides limited liability for its partners. The state's general partnership laws govern the LLP's internal affairs absent contrary provisions. Similar to a general partnership, the partners may vary the default rules governing general partnerships by a written partnership agreement.

Corporations. Although the requirements for forming a corporation vary by state, the general procedure is similar. Formation of a corporation begins with the filing of articles of incorporation with the appropriate state official and paying the required fee. ${ }^{36}$ The articles of incorporation include the name of the corporation, its business purpose, the number of shares authorized to be issued and the par value of such shares, the name and address of the registered agent, and the name and address of the incorporator. ${ }^{37}$ The incorporator is the person forming the corporation and need not be a stockholder or director of the corporation. ${ }^{38}$ If the corporation will have more than one class of stock, the articles of incorporation must also set forth the number of authorized shares and par value of each class of stock and the relative rights and obligations attributed to each class of stock. ${ }^{39}$ After the appropriate state official accepts the articles of incorporation for filing, the state will issue a certificate of incorporation that evidences its legal formation. ${ }^{40}$

In addition to filing articles of incorporation, bylaws must be prepared. Bylaws govern the internal affairs of the corporation, such as the procedures for calling and conducting meetings of the stockholders and board of directors, procedures for electing the directors and officers of the corporation, and the authority and duties of the corporation's directors and officers. ${ }^{41}$ To the extent a particular aspect of the internal affairs of the corporation is not addressed in the bylaws, state corporate statutes, the majority of which are based on the Model Business Corporation Act, provide a default set of rules by which the internal affairs of the corporation are governed. Bylaws need not be filed with any state official.

Additional formation requirements include holding organizational meetings of the stockholders and directors. At the stockholder organizational meeting, the stockholders elect the initial directors of the corporation, unless they have already been named in the articles of incorporation. ${ }^{42}$ At the director organizational meeting, the directors elect the officers, adopt the bylaws, and perform other acts necessary to complete the formation of the corporation, such as adopting resolutions authorizing the officers of the corporation to open bank accounts in the corporation's name. ${ }^{43}$ Finally, shares of stock are issued to the initial stockholders of the corporation, and a record of the issuance of such shares is kept in the corporate records.

Even though all of the foregoing steps are typically required to commence operation of a corporation, basic corporate existence begins when the articles of incorporation are filed and a certificate of incorporation is issued. ${ }^{44}$ 
The corporation is a recognized legal entity as of its date of incorporation, even if bylaws have not yet been adopted and directors and officers not yet elected. If the business owners purport to act for the corporation before it is legally incorporated, an issue arises as to whether or not the limited liability protection applies. This can occur, for example, if articles of incorporation have not yet been filed or are defective because the appropriate state official has not accepted them for filing. By failing to legally incorporate the business, the persons purporting to act for the corporation may be personally liable for the liabilities of the business because they will have simply formed a general partnership.

There are, however, two defenses to personal liability when a purported corporation is defectively incorporated: de facto corporation and corporation by estoppel. A de facto corporation is a partially formed corporation that provides a shield against personal liability of the corporation's owners for the corporation's liabilities. ${ }^{45} \mathrm{~A}$ de facto corporation is established by showing: 1) the organizers of the corporation attempted to comply with the applicable formalities to incorporate but failed to do so; 2) the organizers were unaware of the defect in incorporation; and 3) the business of the company was carried on as though the owners and directors of the corporation believed the corporation was legally formed. ${ }^{46}$ If a de facto corporation is established, the owners are treated the same as shareholders of a legally formed corporation and are not personally liable for the obligations incurred in conducting the business prior to the time the defect in incorporation was discovered.

If the owners of the corporation cannot prove all the necessary elements, they may still be protected from personal liability under the equitable defense of corporation by estoppel. ${ }^{47}$ Corporation by estoppel is transaction specific. It provides that a third party who dealt with the business as though it were a corporation is estopped from asserting personal liability for the business obligations when he later discovers that the corporation was not properly formed. ${ }^{48}$ In some jurisdictions, the equitable defense of corporation by estoppel has been statutorily abolished. ${ }^{49}$

LLCS. Like LPs and corporations, an LLC is formed by filing a formation document with the appropriate state official and paying the required fee. In some jurisdictions, the formation document is called the "certificate of formation" $;{ }^{50}$ in others, it is called "articles of organization." document typically includes the name of the LLC, the names and addresses of the organizers of the LLC, the name and address of the registered agent, a statement as to whether the LLC is member managed or manager managed, and if the LLC is manager managed, the names and addresses of the initial managers. ${ }^{52}$ Once the LLC is formed, the state LLC statutes, some of which are based on the Uniform Limited Liability Company Act, ${ }^{53}$ provide a set of default rules under which the LLC is to be operated. The members generally may vary these default rules by a written operating agreement governing the internal rights and obligations of the LLC and its members. ${ }^{54}$ In particular, the 
operating agreement typically sets forth voting rights, allocation of profits and losses, provisions regarding contributions and distributions, procedures for withdrawal or removal of members and managers, procedures for admission of new members, restrictions on transferability of membership interests, and the manner and process for the dissolution of the LLC.

\section{LIMITATION OF LIABILITY}

When a business association has "limited liability," its owners are shielded from personal liability for liabilities incurred by the business. Although creditors do not have access to personal assets, the businesses assets are fully available to satisfy claims. This limits an owner's liability to the amount of capital they have invested or are required to invest in the business association. Corporations, LPs, LLPs, and LLCs all afford such protection to the owners, and except for the following situations, their stockholders, limited partners, partners, and members are not personally liable for business liabilities.

If an owner of a business association personally guarantees a debt of the business association, then, under contract law, he is personally liable for repayment of that debt if the business association defaults. ${ }^{55}$ If an owner commits a tort in conducting the activities of the business association, he is personally liable for the damages resulting from such tort under principles of tort law ${ }^{56}$ or agency law. ${ }^{57}$ For example, if a partner in a law firm formed as an LLP commits malpractice in the representation of a client of the law firm, such partner may be personally liable for the damages resulting from his or her own negligence. ${ }^{58}$ However, other partners of the law firm are not personally liable for their partner's negligence. ${ }^{59}$

In addition, if a limited partner becomes involved in the management of an LP, he may be held a general partner and thus lose his shield of limited liability. ${ }^{60}$ The RULPA amends this rule and provides a number of statutory safe harbors for management actions a limited partner may take and still retain the shield of limited liability attributable to the LP interest. The safe harbor actions include: 1) being a contractor for, or agent or employee of, the LP or a general partner; 2) being an officer, director, or stockholder of a corporation that serves as a general partner; 3) acting as a surety, guarantor, or endorser for the LP; 4) serving on a committee of the LP or a general partner; and 5) participating in certain decisions relating to the LP, such as removing a general partner, changing the nature of the business of the LP, and dissolving the LP. ${ }^{61}$ If a limited partner engages in an activity that does not fit within the statutory safe harbor, then a court will determine whether such activity constitutes participation in the management of the LP under relevant case law. ${ }^{62}$

Finally, owners of a limited liability business association may be personally liable for business obligations if creditors successfully assert an alter ego, or "piercing the corporate veil," claim. The equitable policy here is that 
owners, or stockholders, who do not run their business as a distinct and separate entity but rather as an "alter ego" of themselves should not be afforded the limited liability protection of the corporate form. ${ }^{63}$ When the corporate veil is pierced, some or all of the corporation's stockholders are personally liable for the obligations of the corporation. Although an alter ego claim is fact-specific, the following factors have influenced courts to "pierce the corporate veil": 1) gross undercapitalization in relation to the foreseeable capital needs of the corporation; 2) failure to observe corporate formalities, such as holding meetings of the stockholders and directors or keeping adequate corporate records; 3) control by one or a few stockholders over the affairs of the corporation; 4) use of fraud or deception in dealing with the corporation's creditors; 5) commingling of the corporation's assets with the personal assets of the stockholder; and 6) abusive self-dealing between the stockholder and the corporation. ${ }^{64}$ The body of law surrounding alter ego claims principally developed in the context of corporations, and ${ }^{65}$ because LLPs and LLCs are relatively recent statutory creatures, the number of cases applying the alter ego theory to them is scarce. The few that do exist, however, suggest the alter ego or piercing theory should be no different in the context of LLPs and LLCs than in the context of corporations. ${ }^{66}$

\section{Governance AND Fiduciary Duties}

The governance of a business association varies depending on the form of business association. General partnerships are based on the fundamental concept that each partner has equal rights to participate in the governance of the partnership, regardless of their respective contributions to or their ownership interests in the partnership. ${ }^{67}$ Therefore, the decision of a majority of partners controls matters related to the ordinary course of business. ${ }^{68}$ The partners may, however, alter this rule in the partnership agreement and delegate governance authority to one or more partners. ${ }^{69}$ In an LP, a limited partner trades his right to participate in the management for limited liability protection. Therefore, the governance of an LP rests with the general partners, and the limited partners have no authority to participate in the management or control of the partnership. ${ }^{70}$ Limited partners may, however, have the right to approve certain fundamental changes to the LP without being deemed to have participated in the management or control of the partnership. ${ }^{71}$ These changes include the amendment of the LP agreement, the merger or dissolution of the LP, and any removal or replacement of a general partner. ${ }^{72}$ LP agreements often require that both the general partners and a supermajority of the limited partners approve certain fundamental changes to the partnership.

In contrast to the partnership scheme of governance, governance of a corporation is representative. The stockholders of a corporation elect the directors who are responsible for the general oversight of the corporation's 
affairs and the establishment of the corporation's policies. ${ }^{73}$ The directors in turn elect the officers who are charged with the day-to-day management of the corporation's operations and who carry out the corporate policies established by the board of directors. ${ }^{74}$ In the corporate setting, ownership of the corporation is clearly separate from its management. The stockholders' rights are limited to voting on the election and removal of the directors and on certain fundamental changes to the corporation such as amendment of the articles of incorporation, the merger or dissolution of the corporation, or the sale of substantially all corporate assets. ${ }^{75}$

State LLC statutes often allow the members of an LLC to choose between a member-managed and a manager-managed LLC. ${ }^{76}$ As in general partnerships, in member-managed LLCs, the decision of a majority normally controls the ordinary course of business, regardless of the members' contributions to or ownership interests in the LLC. ${ }^{77}$ Manager-managed LLCs are similar to the corporate governance structure. Members of the LLC elect the managers of the LLC who in turn elect the officers of the LLC to manage the dayto-day affairs. ${ }^{78}$ The LLC operating agreement typically sets forth operating and governance details, such as voting rights of members, election of managers, if any, contribution requirements, rights to and manner of determining distributions to the members, and procedures for withdrawals or members, transfers of membership interests, and dissolution of the LLC.

When business owners are separate from business managers, as is the case with corporations, the managers ${ }^{79}$ owe certain fiduciary duties to the business association. ${ }^{80}$ If a manager violates a fiduciary duty owed to the business association, he may be personally liable to the business, and ultimately to the owners, for any resulting damages. The scope and nature of a manager's fiduciary duties are defined in case and statutory law and may vary by jurisdiction. They typically include, however, the duty of care and the duty of loyalty. ${ }^{81}$

The duty of care often requires that a manager exhibit honesty and good faith while exercising ordinary and reasonable care in performing his duties. ${ }^{82}$ The duty of care may be breached by either the manager's actions or inactions. If a manager's decision or action turns out to be wrong or results in a loss to the business association, he may be liable for breach of the duty of care. However, because managers' decisions are often evaluated with the benefit of hindsight, courts give great deference to the manager's business judgment at the time he made the decision. ${ }^{83}$ Under the business judgment doctrine, absent fraud, illegality, or conflict of interest, managers are not liable for losses resulting from wrong decisions if there was a rational basis for the decision at the time it was made. ${ }^{84}$ The business judgment rule focuses on the decision-making process, as opposed to actual results, to ensure managers are following sound procedures likely to lead to rational decisions. A manager may also be liable for breach of the duty of care if his inaction causes loss to the business association. For example, directors 
have an affirmative duty to become informed about company performance, to attend meetings regularly, to make an appropriate degree of inquiry, and to act for the general welfare of the corporation. ${ }^{85}$ If a manager simply "puts the blinders on" to mismanagement by co-managers, he may be liable for any resulting losses to the business association.

The duty of loyalty requires managers to put the business's interests before their personal interests. ${ }^{86}$ Duty-of-loyalty claims typically arise in "interested director transactions" and "usurpation of corporate opportunities." The typical "interested director transaction" occurs when both the corporation and a manager are parties to a transaction. For example, if a director sells or leases property to or from the corporation, lends or borrows money from the corporation, or receives compensation from the corporation, he is placed in the position of trying to negotiate the best deal for himself at the same time as negotiating the best deal for the corporation. Because of the temptation for the director to place his personal interests ahead of the corporation's interests, traditional common law made such interested director transactions voidable at the election of the corporation. ${ }^{87}$ Modern state statutes have safe harbor provisions, which, if followed, do not allow the transaction to be voidable by the corporation. ${ }^{88}$ Safe harbor procedures vary by jurisdiction; however, they generally require that the interested director fully disclose his involvement in the transaction to the other directors. They also typically require that a majority of disinterested directors, or if none, a majority of disinterested stockholders, ratify the transaction. ${ }^{89}$

The other type of breach of the duty of loyalty, usurpation of corporate opportunities, arises when managers take company business opportunities for themselves. ${ }^{90}$ This may arise, for example, when an officer or director of a corporation learns of real estate available for purchase or of the ability to invest in a new product line, and he takes for himself what could have gone to the corporation. Defining which opportunities belong to the business association is a difficult task, and the tests determined by the courts vary by jurisdiction and by the facts of the particular transaction. ${ }^{11}$

\section{TAXation of Business Associations}

Taxation of business profits and losses is dependent on the association form. Corporation profits and losses are taxed to the corporation as a separate entity; corporations are responsible for determining their income and deductions, for filing the appropriate tax returns with the Internal Revenue Service, and for paying any tax liability.$^{92}$ Additionally, when a corporation distributes profits to the stockholders as dividends, stockholders are required to report the dividends as taxable income. ${ }^{93}$ As a result, the corporate form of business association provides a "double taxation" of the profits of the corporation: once at the corporate level and once at the stockholder level. 
Conversely, Partnership profits are generally taxed once on a "passthrough" basis. The partnership itself does not pay tax on its profits. ${ }^{94}$ Rather, it files a partnership tax return with the Internal Revenue Service that includes each partner's allocable share of the partnership income and deductions. ${ }^{95}$ Each partner in turn reports his allocable share of partnership income and deductions on his individual income tax return and is responsible for paying the resulting tax liability. ${ }^{96}$ Distributions of partnership profits are tax free to the extent the distributions represent a return on partnership contributions and allocable share of partnership profits. ${ }^{97}$

When available, pass-through treatment ordinarily is preferable to the double taxation applicable to corporations. Special provisions of the Internal Revenue Code allow certain closely held corporations to elect pass-through tax treatment of the corporation's profits. ${ }^{98}$ The income and deductions of these corporations are taxed directly to the stockholders, and distributions of corporate profits to the stockholders generally are tax free. ${ }^{99}$ Such corporations are known as $S$ corporations, named after subchapter $\mathrm{S}$ of the Internal Revenue Code, which contains the provisions that allow for pass-through treatment. To be eligible as an S corporation, the corporation may not have more than 100 stockholders, the stockholders must be individuals, charitable organizations, or certain qualifying trusts, no stockholder may be a nonresident alien, and the corporation may not have more than one class of stock. ${ }^{100}$ It is important to note that S-corporation status is simply a creature of federal tax law and does not affect the limited liability or management of the corporation under state law.

Finally, "check-the-box" Treasury Regulations ${ }^{101}$ allow business associations a great deal of flexibility in choosing how the federal government will tax them. With the exception of corporations formed under state law, which must be taxed as corporations under federal law, ${ }^{102}$ business associations can usually choose their federal tax treatment. Single-member LLCs may choose to be taxed as a corporation or they may choose to be disregarded as an entity separate from its owner for federal tax purposes. ${ }^{103}$ As a disregarded entity, the income and deductions of the LLC are taxed directly to the owner, and distributions from the LLC to the owner are tax free. If the business association has two or more owners, then the business association may elect to be taxed as a corporation or as a partnership for federal tax purposes, regardless of whether it is formed as an LP, LLP, or LLC for state law purposes. ${ }^{104}$ Furthermore, if a business association elects to be taxed as a corporation for federal tax purposes, the business association can further elect to be treated as an S corporation if it meets the eligibility requirements. In any event, the election of the tax treatment of the business association for federal tax purposes does not impact the legal rights and obligations of the business association's chosen form of entity under state law. 


\section{SYLLABUS}

Model Syllabus

This section supplies a model syllabus for a two-credit hour course that focuses on advanced legal research for business associations, assuming the class meets once a week. For each class, students are required to read the assigned materials ${ }^{105}$ and conduct one or more legal research, writing, and citation assignments. Each numbered assignment represents the material that is covered in a single class meeting. For example, Assignment 1 contains the required reading assignment and research assignment for the first class. All recommended assignments and necessary sources for such assignments are described in the corresponding numbered sources contained in the annotated bibliography. ${ }^{106}$ For example, the assignments for the first class are contained in the sources numbered one, fifteen, sixteen, and twenty-five of the annotated bibliography. For some classes, alternative assignments are provided. These alternative assignments are given so an instructor may have a few from which to select for the particular class.

\section{Advanced Legal Research for Business Associations}

\section{COURSE Overview}

The goal of this course is to significantly improve students' legal research, writing, and citation skills through participation in class discussions and completion of numerous research, writing, and citation assignments. More specifically, students will advance their skills by locating and citing primary and secondary law in both print and electronic resources, by becoming more familiar with specific secondary sources relating to business associations, by retrieving pertinent business entity transaction forms, and by assimilating information from primary and secondary legal sources into cogent narratives. Students will also be expected to document their research, writing, and citation processes in a wiki-based research log.

REQUIRED TEXT'S

1. The instructor will provide handouts for all class readings.

2. Darby Dickerson, ALWD Citation Manual: A Professional System of Citation (3d ed., Aspen 2006) (hereafter ALWD).

\section{Course Evaluation}

The student's grade in this course is determined as follows:

Research, writing, and citation assignments $70 \%$

Wiki-based research $\log$ and time statements $20 \%$

Class participation

$10 \%$ 
1. Research, writing, and citation assignments ( $70 \%$ of final grade)

Students are required to complete and turn in fifteen research, writing, and citation assignments throughout the semester. These assignments must be submitted to the instructor at the beginning of class, on the day they are due, as listed in the syllabus. These assignments require students to perform some combination of the following skills: locate and properly cite pertinent primary and secondary sources; draft narrative summaries of business association law issues; analyze questions based on assigned cases or hypothetical fact patterns; and locate official commentary, sample forms, and other relevant material.

2. Wiki-based research log and time statements (20\% of final grade)

Students are required to create a research log on wikispaces.com in which they describe in detail each step taken during a research, citation, or writing assignment. Students need to go to wikispaces.com and set up an account. Students have the option of working individually on each assignment or working in pairs. If working in a pair, students need to set up a joint account. Using a wiki will benefit students because they can collaborate online with their partner about assignments, create valid and reliable research trails, which may help with subsequent assignments, ask the instructor questions, and generate an electronic log to submit to the instructor at the end of the semester. Students will also keep track of their total time spent on each assignment and record this time in their research log. Students are to round to the nearest fifteen-minute increment when recording time spent on an assignment. Students are required to submit their wiki research $\log$ to the instructor electronically on the last day of class. The following is an example of a wiki entry:

I needed to locate a form for the formation of a corporation. Therefore, I used the key words "formation" and "corporation" and looked in the index of the West's Legal Forms form guide. As I looked in the index, I found the subject "corporation." Further, under the term "corporation," I located the subtitle "formation generally," see volume 2 , section 15.1 and section 16.1-16.40. I first looked in section 15.1 and discovered this form was only a checklist and worksheet regarding formation of a corporation. This may be helpful in the formation process, but I needed a more specific form. Therefore, I looked in sections 16.1-16.40 and located a more specific form for this assignment... This assignment took me two hours and thirty minutes to complete.

\section{Class participation (10\% of final grade)}

Students are expected to actively participate in class. The primary factors that will go into a student's class participation grade include the student's level of participation for class as evidenced by the student's 
positive contribution to class discussion and the student's participation in group projects and problems.

\section{ASSIGNMENTS}

Students are required to read all assigned materials prior to the class meeting date. Students must document their research for each assignment in their wiki research $\log$.

Assignment 1 (sources 1, 15, 16, and 25)-Corporations, analyzing substantive law, locating forms, locating and citing pertinent statutory law and case law, drafting, and using Westlaw to locate case law.

Read: ALWD Ch.. 12, 14, 22, 28, and 39; handout: Palmiter, pp. 187-230.

Assignment 2 (sources 7, 9, 16, 18, and 25)-Corporations, statutory research, loose-leaf services, locating statutes via legislature's Web site, drafting a memorandum, proper citation.

Read: ALWD Ch. 5, 6, 12, 14, 22, 23, 27, 28, 38.2, 40.1, and appendix 6; handouts: Cohen \& Olson, pp. 181-185 and 316-324; Model Business Corporations Act Annotated ix- xxxii and 2.01-2.02.

Assignment 3 (sources 10, 16, 22, and 25)_Partnerships, metacognition, statutory and case law research, proper citation, locating pertinent forms.

Read: ALWD Ch. 12, 14, 22, 27, and 28; handouts: Hillman et al., pp. 405-445.

Assignment 4 (sources 7, 12, 16, 20 or 21, and 25)_Partnership formation, using electronic resources, form books, locating forms, proper citation.

Read: ALWD Ch. 28 and 38.2; handout: Cohen \& Olsen, pp. 306-309, 316-324; Chiappinelli, pp. 691-702.

Assignment 5 (sources 4, 8, 16, 17, 22, 23, and 25)-Actual, apparent, and inherent authority, drafting a memorandum, locating relevant material, proper citation, and locating articles via HeinOnline.

Read: ALWD Ch. 5, 6, 12, 14, 22, 23, 27, 38, and appendix 6; handouts: Chiappinelli, pp. 95-111; Ribstein, pp. 19-43; Shade, pp. 18-22, 97-111.

Assignment 6 (sources 11, 13, 16, and 25)_Limited liability companies and partnerships, statutory research, proper citation of secondary and primary resources, drafting a memorandum, and locating case law via LexisNexis.

Read: ALWD Ch. 6, 12, 14, 28, 39, and appendix 6. 
Assignment 7 (sources 4, 5, 16, 17, 22, and 25)-Formation of limited liability companies, proper citation, drafting a memorandum, locating pertinent forms, and locating specific information in a secondary source and via HeinOnline.

Read: ALWD Ch. 6, 12, 14, 22, 27, 28, 38, and appendix 7; handouts: Chiappinelli, pp. 742-747; Shade, pp. 39-41 and 120-122.

Assignment 8 (sources 2, 16, and 25)_Family limited partnerships, transfer of partnership interests, locating and proper citation for primary and secondary law, locating relevant forms, analysis of a problem.

Read: ALWD Ch. 6, 12, 14, 22, and appendix 7; handout: Lewis \& Chomakos, pp. 257-295.

Assignment 9 (sources 6, 13, 16, 23, and 25)—Nonprofit corporations, locating primary law from a secondary source, proper citation, and locating statutory authority via LexisNexis.

Read: ALWD Ch. 6, 12, 14, 22, 27, 28, and 39; handouts: Phelan, pp. 1-1 through 1-72; Ribstein, pp. 519-521.

Assignment 10 (sources 3, 7, 16, and 25)-Sarbanes-Oxley Act, looseleaf research, drafting a memorandum, locating secondary and primary sources, and proper citation.

Read: ALWD Ch. 5, 6, 12, 14, 15, 16, 19, 22, 28, and appendix 6; handout: Cohen \& Olson, pp. 315-339.

Assignment 11 (sources 16, 19, and 25)—Researching publicly traded companies via Hoovers electronic database.

Read: ALWD Ch. 38 and 40.

Assignment 12 (sources 13, 14, 16, and 25)-Using electronic resources to locate forms, proper citation.

Read: ALWD Ch. 38, 39, and 40.

Assignment 13 (sources 15, 16, and 25)-Using electronic resources to locate articles, forms and case law, and proper citation.

Read: ALWD Ch. 12, 23, 38, and 39.

Assignment 14 (refer to sources 16, 20, 21, and 25)-Using form guides to locate forms, tax analysis, and substantive explanations.

Read: ALWD Ch. 6, 12, 14, 27, 28, and 42. Make a log entry and record your time. 


\section{Assignment 15 (sources 16, 24, and 25)-Using digests to locate case law, proper citation.}

Read: ALWD Ch. 12.

\section{COURSE RESOURCES}

Annotated Bibliography

General Business association Treatises, Monographs, and Guides

1. Alan R. Palmiter, Corporations: Examples E Explanations (5th ed., Aspen 2006).

This soft-bound monograph is divided into eight different parts which provide detailed analysis of the following concepts: an overview of corporate law history; formation of the corporation; shareholder voting rights; corporate fiduciary duties; shareholder liquidity rights; closely held corporations; protections for corporate creditors; and corporate fundamental changes. Each of the eight parts is broken up into multiple chapters. At the end of each chapter, the author presents several fact patterns and questions concerning a topic. Immediately following the questions, the author provides sample answers and analysis for each question.

This monograph is an excellent source for creating research assignments. For example, students can be assigned to read from Sections 11 and 12, which discuss the duties of care and loyalty and the business judgment rule. Then, students should answer the questions at the end of Section 12. Sample answers are provided at the end of Section 12. Additionally, students can be required to locate a form regarding the duties of care and loyalty, such as a conflict of interest policy, and draft a short section of a policy that explains the basic duties of directors or officers of a corporation. Finally, students can be instructed to give proper citation to this source, to any form book used, and to any statute, case law, or other primary or secondary sources used.

2. David T. Lewis \& Andrea C. Chomakos, The Family Limited Partnership Deskbook: Forming and Funding FLPs and Other Closely Held Business Entities (2d ed., ABA Publishing 2007).

This monograph presents an in-depth analysis of forming, funding, and operating a family limited partnership (FLP) or a family limited liability company (FLLC), offers examples of proper drafting, explains valuation principles regarding FLPs and FLLCs, and presents basic and advanced analysis of income tax concerns for FLPs and FLLCs. This 
source also offers pertinent forms and references to relevant statutes, case law, Treasury Regulations, Internal Revenue Code sections, and other related primary and secondary legal sources.

Chapters in this book are organized into three different sections: client example sections, notes sections, and exhibit sections. The client example sections present fact patterns that can be used to create research assignments. The notes sections refer to primary and secondary sources pertinent to a specific topic discussed in a fact pattern. The exhibit sections proffer form guides for drafting.

This monograph can therefore be used to have students research issues presented in a fact pattern, draft a response to these issues, give proper citation to all primary and secondary sources used to formulate an answer, and locate a relevant form guide. For example, students can be presented with a problem concerning the transfer of LP interests. Then, they can read Chapter 8 of this monograph to develop an understanding of the rules associated with the transfer of LP interests. Next, students may use the notes section of Chapter 8 to locate secondary and primary sources related to this area of substantive law. Then, they may use the exhibit section to gather any necessary form guides. Finally, students may draft an appropriate response and give proper citations to all primary and secondary sources implemented.

\section{John T. Bostelman, The Sarbanes-Oxley Deskbook (P.L.I. 2003).}

This deskbook focuses on issues evolving from Sarbanes-Oxley legislation enacted to address corporate and accounting scandals. This source is in a loose-leaf format and is updated via different releases throughout the year. It consists of three volumes and is broken into nine parts. Each part is divided into many chapters. The major subjects discussed in this source consist of background information about SarbanesOxley, issuer reporting, governance, auditors, attorneys, ancillary gatekeepers, miscellaneous information, and remedies and penalties. This source also offers appendices and a helpful index.

Various research activities can be assigned to demonstrate how this deskbook can help initiate research. For example, students can be asked to draft a memorandum describing how the quasi-public agency called the Public Company Accounting Oversight Board is funded. Students can use the index of this source and discover that Volume 2, Part 4, Chapter 17 of this deskbook discusses this topic. Chapter 17 also refers to other sources that offer information about this topic, such as white papers, annual reports, Senate and House committee reports, the Code of Federal Regulations, and other pertinent primary and secondary sources. Consequently, students can draft a memorandum and also be instructed to cite this source and all primary and secondary sources referred to in Chapter 17. 
4. Joseph Shade, Business Associations in a Nutshell (2d ed., West 2006).

This softbound monograph provides a detailed overview of substantive law concerning business associations. Some of the substantive topics covered in this book include selecting a type of business association; how to form a business association; the limits of limited liability; decision making in the operation of a type of business; legal duties of decision makers; protections for individuals who buy or sell securities; how businesses raise money; how business owners generate money; and how to terminate a business entity. This monograph further offers users a general index to locate pertinent topics, a table of cases, references to federal, uniform, and model acts, and case law relevant to business associations.

Students may find this a helpful reference for understanding business association terms and phrases and the general substantive area of law. The terms, phrases, and general areas of substantive law are cogently explained via simple, short narrative fact patterns. This source may also be a useful supplement to any of the suggested assignments.

Additionally, the author contrasts different judicial and congressional approaches to specific legal issues. For example, the author analyzes how Delaware, New York, and some minority jurisdictions resolve specific disputes relating to business associations. Therefore, students can be instructed to draft a narrative describing the differences between the New York, Delaware, and the Model Business Corporation Act approaches in dealing with the demand requirement in shareholder derivative suits. A portion of Chapter 6 conveys these differences. Students could then be required to properly cite this source and all other secondary and primary sources used.

\section{J. William Callison \& Maureen A. Sullivan, Limited Liability Companies: A} State-by-State Guide to Law and Practice (West 2008).

This three-volume guide offers discussion and explanations of substantive law concerning LLCs, information regarding statutory materials relating to LLCs, references to other pertinent primary and secondary sources, and forms relevant to LLC transactions. Some of the topics discussed in Volume 1 include choice of entity, formation of an LLC, members, member's liability, capital contributions, distributions and profit and loss sharing, governance, management and control, member withdrawal and disassociation, and extraterritorial recognition of LLCs. A few of the primary and secondary sources referenced in this source include published and unpublished case law, statutes, revenue rulings, Restatements of the Law, West's key numbers, and legal encyclopedias. Volume 1 also contains a summary of LLC laws of all fifty states, and sample forms for LLC transactions.

Volume 2 of this guide presents selected sections from the Internal Revenue Code, various Treasury Regulations, specific Revenue Rulings, and the full text of the Uniform Limited Liability Company Act 
of 1996 (ULLCA). In addition, Volumes 2 and 3 contain each state's version of the ULLCA.

Students can use this source to locate and provide proper citation to the section of this source that discusses formation of LLCs. Then, students can be asked to give proper citation to four primary sources and four secondary sources referred to in this section. Students can also be required to locate and draft a summary of the requirements for formation of LLCs in four separate jurisdictions. Alternatively, students might be required to locate and cite a jurisdiction-specific form regarding the formation of an LLC.

6. Marilyn E. Phelan, Nonprofit Enterprises: Corporations, Trusts, and Associations (West 2000).

Including a source pertaining to nonprofit organizations gives some additional context in which students can compare and contrast the law of business associations. This treatise is presented in loose-leaf format and is separated into three volumes. It is updated annually with a supplement and with annual releases. The first two volumes of this treatise are divided into twenty-seven chapters. Some of the topics included in the first two volumes consist of creation of a nonprofit corporation, members and directors of a nonprofit corporation, liability of members and directors, federal tax-exempt status, public charities, private foundations, fund raising, churches, hospitals, schools, and museums. Volume 3 contains appendices with pertinent tax forms, copyright forms, U.S. Code sections relating to nonprofit corporations, the Model Nonprofit Corporation Act, the Revised Model Nonprofit Corporation Act, the Uniform Unincorporated Nonprofit Association Act, tables of statutes, rules and regulations, a table of cases, and an index.

This source may be implemented to teach students how to use a secondary source to locate primary sources such as relevant statutes and germane case law. For example, students can be asked to draft a discussion of how the doctrine of charitable immunity has historically affected and how this doctrine currently affects tort liability of hospitals. Using the index, students can discover section 21:22 discusses these topics. Therefore, by using section 21:22 and all primary and secondary sources referred to in this section, a student can draft a summary of this topic. Then, students can be asked to give proper citation to this source and to all other primary and secondary sources used.

7. Morris L. Cohen \& Kent C. Olson, Legal Research in a Nutshell (9th ed., West 2007).

This monograph offers an overview of strategies to locate primary and secondary legal sources. Topics in this monograph that are relevant to 
this course include researching case law (Chapter 4), statutory research (Chapter 5), and topical research sources (Chapter 9). This source can be used to supplement various class assignments.

8. Stephen M. Bainbridge, Agency, Partnership, \& LLCs (Foundation Press 2004).

This monograph presents general discussions of germane topics usually covered in a business associations course. Some of these topics include agency relationship, liability of a principal, duties of agents, management rights of partners, liabilities of partners, fiduciary obligations of partners, dissolution of partnerships, formation of LLCs, governance of LLCs, freedom of contract, types of authority, dissociation, and dissolution of LLCs. Within each topical discussion, the author provides references to relevant case law, statutory material, articles, models acts, Restatements of the Law, and other primary and secondary sources.

Students can implement this source by drafting a narrative comparing actual, apparent, and inherent authority (or a comparison of other substantive areas). These types of authority are discussed in Chapter 2 of this source. Students can be required to support their comparisons with ample primary and secondary sources. Therefore, to complete this assignment, students may use this monograph, other primary and secondary sources referenced in this monograph, and other sources referenced in this annotated bibliography. Finally, students should be required to properly cite this source and all other primary and secondary sources used for this assignment.

\section{STATUTORY MATERIALS AND GUIDES}

9. Model Business Corporation Act Annotated (Michael P. Dooley \& William S. Potter, eds., 4th ed., ABA 2008).

The Model Business Corporation Act Annotated is a loose-leaf, fourvolume set containing the full text of the Model Business Corporation Act, the Model Professional Corporation Supplement, and the Model Close Corporation Supplement, all with official comments and reporters' annotations. The Model Business Corporation Act may be enacted in whole or in part by a state legislature. Currently, twentynine states have adopted a version of this model act. At the end of each section of the Model Business Corporation Act, a comparison of how different states have or have not enacted various nuances of that particular section is presented. For example, at the end of section 2.02, one is presented with a comparison of how states such as Colorado, Connecticut, Florida, Georgia, and others have adopted section 2.02 of the Model Business Corporation Act of 1984, which 
permits but does not require the articles of incorporation to state the purposes for which the corporation is organized. However, Tennessee's adopted version of section 2.02 requires the articles of incorporation to state that the corporation is for profit. Further, Arkansas, Minnesota, and other states have adopted statutes similar to section 2.02 of the Model Business Corporation Act of 1984. At the end of each section, this source also provides references to law reviews, treatises, statutes, statutory comparisons, case law, and other legal materials that convey information pertinent to that section. Therefore, using this source, students can be given a specific code section (such as section 2.02) and then be asked to draft a narrative comparing different states' adoption, partial adoption, or lack of adoption of that section. Students can also be asked to properly cite the section of this source in which the assigned model code section is located. Alternatively or concurrently, students can be directed to locate and give proper citation to pertinent case law, law review articles, treatises, and other pertinent material referenced in the assigned model code section.

10. Robert W. Hillman, Allan W. Vestal \& Donald J. Weidner, The Revised Uniform Partnership Act (West 2009).

This softbound monograph offers users the full text of the RUPA, a section-by-section analysis that includes the official comments, and comments written by the authors. This monograph also provides sample forms for specific transactions. Additionally, this source has an appendix that indicates which states have adopted RUPA and where specific sections of a state's version of RUPA are located within a state's code. This source also includes a table of laws and rules, a table of cases, and an index.

This monograph is suitable for several different research assignments. One option is to assign students a metacognitive action that forces them to think about their research steps. A metacognitive assignment requires students to create their own questions and answers for a project. Such a metacognitive task can consist of giving proper citation to ten states' codes that have adopted a specific section of RUPA, such as dissolution of a partnership (sections 801-807), and locating relevant forms. Alternatively, students can use this book to create questions and answers pertaining to locating primary and secondary law referenced in the official comments and in the authors' comments in certain sections and then giving proper citation to those sources. Another option is to use this source for historical research, because this monograph also contains the text of the 1914 version of the Uniform Partnership Act. 
11. State Limited Liability Company \& Partnership Laws (Michael A. Bamberger, ed., Aspen 1995).

This treatise consists of five volumes, each of which is divided into separate sections organized by jurisdiction. Each section offers a particular jurisdiction's LLC act with annotations and selected forms. Additionally, each section has practice guides that give cogent, jurisdiction-specific instructions regarding the tax status of LLCs, the formation of an LLC, amendment of articles of organization, dissolution of an LLC, and other relevant information. Also, Volume 1 proffers a practical guide to LLCs, the ULLCA, and a table of cases.

Students can be asked to use this source to locate the statutory requirements for properly listing an LLC's name in the following jurisdictions: the District of Columbia, Connecticut, Delaware, Rhode Island, and Texas (or other jurisdictions). The practice guides in this source precisely list the naming requirements for each jurisdiction and refer to statutory authority for such requirements. Students can list these requirements and be instructed to give proper citation to this treatise, to each jurisdiction's statutory authority, and to any other primary or secondary sources used.

An alternative or concurrent assignment can require students to locate, compare, and contrast ten separate states' statutory authority and interpretive case law regarding members' rights to information and voting in LLCs. Students can locate this information in each state's version of the ULLCA contained in this treatise. Each state's version of the ULLCA contains annotations leading a user to case law and secondary sources within that jurisdiction which have interpreted a statute. Students can use these statutes, case law, and any secondary authority to draft a comparison of the ten different state's approach to members' rights to information and voting in LLCs. They can also be required to give proper citation to this treatise and to all primary and secondary authority used.

\section{ELECTRONIC RESOURCES}

12. The Center for Computer-Assisted Legal Instruction (CALI) (available at http://www.cali.org).

CALI offers interactive lessons for law students in numerous areas of substantive and procedural law. Forty-two lessons pertain to business associations. Some of these lessons include partnership issues, authority, the business judgment rule, corporate distributions, issuance of shares, agent's liability, master and servant issues, shareholder voting, and valuation. Each lesson offers a narrative and examples that explain current primary law. The lessons also offer multiple-choice questions which verify students' understanding of the topics. 
These lessons can be used as a valuable supplement to jumpstart a research project by giving students a basic knowledge of a substantive area of law. For example, students can be required to complete a lesson, titled "Has a partnership formed?" For proof of completion of an assignment, students can be required to print and turn in their CALI proof-of-completion certificate. Concurrently, students can be asked to locate a sample annotated form regarding the formation of a partnership from one of the form guides mentioned in this annotated bibliography. Next, students can be directed to list some of the factors to consider when drafting a partnership agreement. Finally, students could be required to properly cite this database, any form books used, and any other primary or secondary source used.

\section{LexisNexis (available at http://www.lexis.com).}

LexisNexis offers numerous state-specific and general forms related to business association transactions. For example, the Business Transactions LexisNexis Forms source contains forms for partnerships, closely held corporations, joint ventures, LLCs, LLPs, unincorporated associations, and other types of business entities. Students can be assigned to locate forms from this source such as a form related to "removal of a general partner in Pennsylvania." To locate such a form, one should first locate and open the Business Transactions LexisNexis Forms database. Next, click on "limited partnership," then click on "dissolution and winding up," and then, click on "Pennsylvania." After that, enter the following terms and connector search: removal w/s general $\mathrm{w} / \mathrm{s}$ partner. This search retrieves a couple of relevant forms such as Form 436-48.200. Prior to this assignment, students must have learned how to locate specific databases in LexisNexis and how to perform a terms and connector search.

LexisNexis can be used to supplement other assignments as well. For example, students can be instructed to use LexisNexis to locate case law about how charitable immunity affects tort liability of hospitals (Assignment 9). Also, LexisNexis can be used to look up specific sections of the ULLCA and sections of states' versions of the ULLCA (Assignment 6).

\section{State's Secretary of State Office Web site}

Most states' Secretary of State Web sites contain basic forms used to create different types of businesses entities in that jurisdiction. For example, the Texas Secretary of State's Web site offers forms relating to the formation of for-profit corporations, nonprofit corporations, LLCs, LPs, and other types of business entities. Students can be required to locate and download a form used to form a specific type of business entity from a specific state's Secretary of State Web site. 
Then, students can be asked to give proper citation to the Web site from which they retrieved the form.

15. Westlaw (available at http://www.lawschool.westlaw.com).

Westlaw contains several databases pertinent to business associations. For example, the Business Entitites (WGL-BUSENT) database contains articles that discuss various business association issues. Most articles in this database focus on choosing and structuring a business entity. Also, the Forms for Small Business Entities (FRMSMBUS) database contains forms for small business entities such as general partnerships, LPs, closely held corporations, and LLCs. Further, the Choice of Business Entity (CHOICEBE) database offers a book that compares the similarities and differences of various types of business associations. Westlaw also allows students to locate primary and secondary sources via a custom digest search.

Students can be asked to locate two articles pertaining to the tax treatment of LLCs in the WGL-BUSENT database. To locate these articles, students can be taught to form a title field, terms and connector search such as: TI (tax/s treatment/2 llc). By using this terms and connector search, students can locate two relevant articles. Students can then be required to give proper citation to these articles. Alternatively or concurrently, students could be required to locate specific forms from the FRMSMBUS database. For example, students can be directed to locate a letter agreement between a music ensemble and new member for a partnership or joint venture. By entering the following terms and connector search, students should find a relevant form: letter/ 1 agreement/s music/ 1 ensemble/s member. Also, alternatively or concurrently, students could be asked to form a custom digest in Westlaw to locate all cases in a specific jurisdiction that discuss when a partnership officially begins. Students should be shown in advance how to form a custom digest search in Westlaw. Finally, students can be instructed to properly cite each case retrieved.

Westlaw can be used to supplement other assignments as well. For example, students can use Westlaw to retrieve cases regarding duties of care and loyalty for a corporation and the business judgment rule (Assignment 1). Westlaw can be used to teach students how to locate resources such as white papers, annual reports, Senate and House reports, and the Code of Federal Regulations in electronic format (Assignment 10). Further, Westlaw can be implemented in teaching students how to locate a specific section of the RUPA and which states have adopted that section (Assignment 3).

16. Wikispaces (available at http://www.wikispaces.com).

Wikispaces is a user-friendly, free, open-source venue. It allows individuals to collaboratively create and edit a wiki. While using a 
wiki, one can limit who may author, edit, and view a wiki. It is an excellent resource to use for class projects, work space, and other shared projects. Thus, students can use wikispaces.com to create their research $\log$ for this class. An instructor can also use wetpaint.com or http://pbworks.com for student wikis.

17. HeinOnline (available at http://heinonline.org).

HeinOnline's law journal library contains approximately 2,000 different titles. One may assign students to locate four law journal articles that discuss the requirements of forming an LLC (Assignment 7). One may also use HeinOnline in requiring students to locate four law journal articles addressing actual, apparent, and inherent authority (Assignment 5). Students should be required to properly cite their retrieved articles as well.

18. State legislature's Web site

Most states' legislatures offer their adopted version of the Model Business Corporation Act via their Web sites. Therefore, students may be required to visit ten separate state legislatures' Web sites and view the full text of each of these states' adopted version of the Business Corporation Act. Then, they can be required to compare several different sections of these states' codes (as referenced in Source 9 for Assignment 2). Such an alternate assignment gives students an opportunity to learn how to access these statutes via an electronic resource. Students can also be asked to properly cite each of the assigned statutory sections.

19. Hoovers (available at http://hoovers.com).

Hoovers allows one to locate information on more than twenty-eight million publicly traded companies. Available information includes financial statements, ticker symbols, stock information, initial public offering filings, and Standard Industrial Classification (SIC $)^{107}$ and North American Industry Classification System (NAICS) ${ }^{108}$ codes. Using this site, students may be assigned to locate and print financial statement filings, ticker symbols, and the SIC and NAICS codes for ten separate publicly traded companies. Students may also be required to cite the Hoovers database. Prior to this assignment, the instructor should demonstrate how to locate such information. If an instructor prefers, he or she could locate the same information using EDGAR Online (available at http://www.Edgar-online.com) or LexisNexis Academic (available at http://academic.lexisnexis.com). 
FORM GUIDES

20. Jacob Rabkin \& Mark H. Johnson, Current Legal Forms with Tax Analysis (LexisNexis 2008).

This source thirty-four volume loose-leaf set is updated periodically and also available on CD-ROM. Each volume covers a different substantive topic. The topics pertinent to business entities are: Volume 1 (partnerships); Volume 7 (sales of stocks and business assets); Volume 19 (not-for-profit corporations); Volume 20 (corporate reorganizations and liquidations); Volume 21 (professional corporations); and Volume 22 (corporate organization, corporate operation and management, and LLCs).

Each volume is broken into four parts: tax background, practice background, drafting guidelines, and forms. The tax background discusses tax issues that may arise while completing a transaction. The practice background offers a brief overview of substantive law to be considered while drafting a transaction. ${ }^{109}$ Additionally, the practice background offers a chart that compares and contrasts how substantive law is applied in different business entities (e.g., partnerships, corporations, and S corporations). The drafting guidelines part is helpful in that the author walks users through the drafting process with explanations of why certain clauses and language are necessary in specific transactions. In addition, this part offers users a drafting checklist to ensure all necessary provisions of an agreement are included. The forms part contains sample forms one may implement for a transaction.

This form guide can be used by students to write a brief narrative explaining a particular area of substantive law and to list some specific clauses necessary for a specific transactional agreement. For example, students may be asked to draft a narrative concerning the rights and duties of partners in a partnership. To complete the narrative, students may refer to the practice background in Volume 1 (which discusses partnerships) to locate references to substantive law such as RUPA, case law, and other primary legal sources. Then, students may use the drafting guidelines and forms sections to discover what language, clauses, and specific forms are necessary to draft the assigned agreement. Finally, students can be asked to properly cite all primary and secondary authority used during this assignment.

An alternative or concurrent assignment could be requiring students to write a narrative comparing and contrasting the differences in an area of substantive law pertaining to a partnership, an S corporation, and a corporation. Students could generate a comparison from the chart located in the practice background section in one of the relevant volumes. Finally, students could be required to properly cite the sections used in this source. 
21. Paul Lieberman et al. West's Legal Forms (4th ed., West 2007).

West's Legal Forms is a multivolume set and offers an abundant array of legal forms, checklists, and suggestions for different areas of substantive law. It is updated with annual pocket parts. Nineteen of the volumes are relevant to business entity transactions. These relevant volumes consist of Volume 1 through Volume 6-A. Each volume is divided into multiple chapters. Most chapters begin with a general discussion of a main thesis and then follow with a more detailed articulation of each topic. Also, most chapters present sample forms with several options and drafting suggestions. Additionally, each volume presents succinct tax analysis for specific transactional scenarios involving business associations. This set further includes a helpful softbound index which includes a volume summary, volume contents, and an extensive subject index.

This source can be used to have students locate specific forms for various business transactions. For example, students can be asked to locate precise sections of forms to draft: 1) an assumed name certificate for a partnership (located in Volume 1A, Section 9.12); 2) a general notice of a trustee meeting (located in Volume $1 \mathrm{H}$, Section 9.2); and 3) a dissolution agreement for a cooperative (located in Volume 1I, Section 13.11). Subsequently, students can be asked to properly cite the sections of this source from which the forms are obtained. One can also direct students to use this set as an expository source for an understanding of substantive business association topics and possible tax consequences.

\section{CASEBOOKS}

22. Eric A. Chiappinelli, Cases G Materials on Business Entities (Aspen 2006).

This casebook can be used to assign students research exercises and to allow students to familiarize themselves with various substantive topics related to business associations. This source contains fourteen separate chapters broken up by subjects. Subjects included are corporate law, businesses, economics, agency, incorporation process, capital formation, distributing money to shareholders, dealing with creditors, how corporations take actions, board's powers, duties of loyalty and care, standards of review and restrictions. Additionally, this casebook has a 2007-2008 supplement written by the author.

The casebook and the supplement contain notes and questions at the end of most cases. These notes and question segments are valuable for teaching an advanced research and writing class. They provide ready-made, thought-provoking research questions for students. These notes and question segments are divided into five types. First are the "Notes," which provide factual information about the preceding case or a particular transaction. Second is the "Reality Check," 
which includes questions designed to make one comprehend the preceding case, transaction, dispute, or resolution. Third is the "Suppose" section that requires students to analogize from the previous fact pattern. Fourth is the "What Do You Think?" section, which requires analysis of policy. Finally, the "Draft It Yourself" section requires students to draft their own documents related to business entities.

Each of these sections could be used as a catalyst for a research assignment requiring students to examine substantive issues and then give proper citation to primary and secondary authority. For example, students can be assigned a case to read, a Reality Check section to read, and then a drafting exercise from the Draft It Yourself section. Subsequently, students can be required to cite this casebook and any pertinent statutes or case law located while drafting an agreement.

23. Larry E. Ribstein, Unincorporated Business Entities (3d ed., Anderson Publishing 2004).

This casebook is a second option, or it may be used as a supplement to Chiappinelli's casebook to further teach students about unincorporated business associations. It is divided into fourteen separate chapters. The general subjects discussed in these chapters include agency and the sole proprietor, forming the partnership, partner's financial rights, management and control, partner's vicarious liability, partner's property rights, fiduciary duties and remedies, dissolution and dissociation causes, incorporated partnerships, LPs, tax considerations, LLPs, and emerging directions for unincorporated firms. Each chapter also offers students notes and problems concerning business planning and drafting issues, an analysis of pertinent case law, and references to relevant statutes. Another benefit of this source is it aggregates materials from different areas of the law such as tax, bankruptcy, securities, and other areas that affect business planning. In addition, an appendix provides a sample annotated operating agreement which is referenced throughout the chapters.

This casebook can be used to garner a better understanding of substantive law relating to unincorporated business entities. Also, the notes, problems, and sample annotated operating agreement can be used to form research exercises for students. For example, students can be assigned to draft a narrative and a partial agreement regarding fiduciary duties that are in issue in one of the problems located in Chapter 8 , which discusses fiduciary duties and remedies. Students may then use the case law and statutes analyzed in Chapter 8 , the sample agreement in the appendix, and any other primary or secondary source referenced in this chapter to draft an appropriate response and a sample agreement. Subsequently, students can be required to properly cite all case law, statutes, this case book, any forms used, and any other primary or secondary law used in drafting the narrative and the agreement. 


\section{DigesT}

24. West's Federal Practice Digest (4th ed., West 2002).

This digest is used as a finding tool to locate federal case law. It offers a helpful descriptive word index to look up general topics or phrases. The index points to a volume that references topics and key numbers and cases that discuss these general topics and phrases. Therefore, this source can be used to have students look up several topics or phrases such as "piercing the corporate veil" and "acts of incorporation," and locate ten separate cases per topic from various jurisdictions. Then, students can be required to properly cite each of the located cases.

\section{Citation Manual}

25. Darby Dickerson, ALWD Citation Manual: A Professional System of Citation (3d ed., Aspen 2006).

This citation manual enables students to form proper citation for materials used in this class. This citation manual offers a useful index to locate pertinent citation rules. Some of the following chapters are especially important for this class: Chapter 5 (page numbers); Chapter 6 (citing sections and paragraphs); Chapter 12 (case law); Chapter 14 (statutory codes); Chapter 15 (other federal legislative materials); Chapter 16 (other state legislative materials); Chapter 19 (federal administrative and executive materials); Chapter 22 (books, treatises, and nonperiodic materials); Chapter 23 (legal and other periodicals); Chapter 27 (restatements, model codes, and uniform laws); Chapter 28 (loose-leaf materials); Chapter 37 (unpublished works); Chapter 38 (electronic citation); Chapter 39 (Westlaw and Lexis materials); Chapter 40 (World Wide Web resources); chapter 42 (CD-ROM materials).

\section{NOTES}

1. Rev. Unif. Partn. Act $\S 202(a)$ (amended 1997).

2. Id. at $\S 306(\mathrm{a})$.

3. The Revised Uniform Partnership Act generally requires a creditor to first seek satisfaction of the creditor's claims from the partnership before seeking to hold the partners personally liable. See Rev. Unif. Partn. Act $\S 307$ (d)(1).

4. Infra "Taxation of Business Associations."

5. In addition, some states recognize professional associations, professional corporations, or professional limited liability companies as additional forms of business associations for qualifying professionals. See e.g., Tex. Bus. Org. Code tit. 7. Because these organizational forms are available only for certain professional businesses (such as a medical practice, a law practice, or an accounting practice), the discussion of these forms of business associations is beyond the scope of this article. 
6. This is due, in large part, to the requirement that a business be incorporated to have ownership interests in the business publicly traded on the major stock markets.

7. Model Bus. Corp. Act. $\S \S 10.03,10.20,11.04,12.01,14.02$ (ABA 2008). Different classes of stock may be issued with varying rights to distribution of profits or with varying restrictions on a stockholder's voting rights. This article discusses the rights commonly associated with stock ownership. Major events include changes to the corporation's governing documents, dissolution of the corporation, merger of the corporation with another entity, and the sale of substantially all of the corporation's assets.

8. Id. at $\$ \S 7.28,8.01(\mathrm{~b})$.

9. Id. at $\S 6.22$. Under limited circumstances, a creditor may reach a stockholder's personal assets in satisfaction of the corporation's obligations. These circumstances are discussed in "Limitation of Liability" infra.

10. Infra "Taxation of Business Associations."

11. See I.R.C. \& 301.

12. See Rev. Unif. LP Act $\& 101(7)$ (amended 1985) (hereafter RULPA); Rev. Unif. LP Act $\$ 102(11$ ) (amended 2001) (hereafter Re-RULPA).

13. See RULPA $\S 403$; Re-RULPA $\S 404(a)$.

14. See RULPA $\S 303(\mathrm{~b})(6)$; Re-RULPA $\$ 302 \mathrm{cmt}$.

15. See RULPA $\S 303(b)(6)$; Re-RULPA $\S \S 401(4), 603(4)$.

16. See RULPA $\S 303(a)$; Re-RULPA $\S 303$.

17. Unif. LLC Act $\S 404(\mathrm{a})(1996)$.

18. Id. at $\S 404(\mathrm{~b})$.

19. Rev. Unif. Partn. Act $\$ 306(c)$; Unif. LLC Act $\& 303(a)$.

20. See Rev. Unif. Partn. Act $\S 202(a)$. Because no written agreement of the partners is necessary to form a general partnership, the Revised Uniform Partnership Act provides certain statutory guidelines to aid in determining whether the parties have created a general partnership under relevant state law. See id. at $\S 202$ (c).

21. Likewise, no particular formalities are required to form a sole proprietorship, and a sole proprietorship is the default form of business association when an individual conducts business without taking the necessary legal action to create another form of business association.

22. See Martin v. Peyton, 246 N.Y. 213, 217-18 (1927) ("Partnership results from contract, express or implied. ... Mere words will not blind us to realities. Statements that no partnership is intended are not conclusive. If as a whole a contract contemplates an association of two or more persons to carry on as co-owners of a business for profit, a partnership there is.").

23. See Rev. Unif. Partn. Act $\$ 306(a)$.

24. The Uniform Partnership Act was initially promulgated in 1914 by the National Conference of Commissioners on Uniform State Laws and was adopted in substantially similar form in every state except Louisiana.

25. The Revised Uniform Partnership Act was initially promulgated in 1992 by the National Conference of Commissioners on Uniform State Laws and was amended in 1993, 1994, 1996, and 1997. The vast majority of states have adopted some variation of the Revised Uniform Partnership Act as the basis for their general partnership laws, although substantial variations exist from state to state.

26. Rev. Unif. Partn. Act $\S 103$ (a). Certain provisions of the Revised Uniform Partnership Act may not be altered by the partnership agreement. See id. at $\S 103(\mathrm{~b})$.

27. See RULPA $\& 201(a) ;$ Re-RULPA $\$ 201(a)$.

28. RULPA $\S 204(a)(1)$; Re-RULPA $\S 204(a)(1)$.

29. RULPA $\S 201(a)$; Re-RULPA $\S 201(a)$.

30. The RULPA was promulgated in 1976 by the National Conference of Commissioners on Uniform State Laws and was amended in 1985. The limited partnership laws in a vast majority of the states are based on the RULPA. The RULPA was amended again in 2001. The 2001 amendments were numerous and in many cases significant. See generally Thomas E. Geu \& Barry B. Nekritz, Expectations for the Twenty-First Century: An Overview of the New Limited Partnership Act, 16 Prob. \& Prop. 47 (Jan./Feb. 2002), describing the substantial revisions made by the 2001 amendment. Approximately one-third of the states have adopted the RULPA as amended in 2001.

31. See RULPA $\$ \S 101(9), 1105$; Re-RULPA $\$ 110$. Certain provisions of the Revised Limited Partnership Act may not be altered by the partnership agreement. See Re-RULPA $\S 110$ (b).

32. Rev. Unif. Partn. Act $\S 1001(c)$. 
33. Id. at $\$ 1001(\mathrm{c})$.

34. See e.g., Tex. Bus. Org. Code Ann. $\S 152.804$ (2008).

35. See Rev. Unif. Partn. Act at $\$ 1003(\mathrm{c})$.

36. Model Bus. Corp. Act $\S 2.01$.

37. Id. at $\S 2.02$.

38. Id.

39. Id. at $\S 6.01(\mathrm{a})$.

40. Id. at $\S 2.03$.

41. Id. at $\S 2.06$

42. Id. at $\S 2.05(\mathrm{a})(2)$.

43. Id. at $\$ 2.05(\mathrm{a})(1)$.

44. Id. at $\$ 2.03$.

45. Cranson v. Intl. Bus. Mach. Corp., 200 A.2d 33, 34 (Md. 1964).

46. $I d$.

47. Id.

48. Id.

49. The Model Business Corporation Act abolishes corporation by estoppel by explicitly imposing liability on parties who purport to act on behalf of a corporation without first incorporating. Model Bus. Corp. Act $\S 2.04$.

50. See e.g., Del. Code. Ann. tit. 6, § $18-201$ (Lexis 2005 \& Supp. 2008).

51. See e.g., Cal. Corp. Code Ann. § 17051 (West 2006); Wyo. Stat. Ann. § 17-15-107 (2007)

52. Id. at $\S 203(\mathrm{a})$.

53. The ULLCA was promulgated in 1996 by the National Conference of Commissioners on Uniform State Laws. The ULLCA has been adopted in a number of jurisdictions. A Revised ULLCA was promulgated in 2006 . For a discussion of the major revisions made in 2006, see generally Daniel S. Kleinberg \& Carter G. Bishop, The Next Generation: The Revised Uniform Limited Liability Company Act, 62 Bus. Law. 515 (2007). The Revised ULLCA has been adopted in two jurisdictions. However, there are many jurisdictions which have adopted limited liability company statutes not based on the ULLCA or the Revised Limited Liability Company Act. Accordingly, the limited liability company laws may vary widely from state to state.

54. Unif. LLC Act $\S 103($ a). The operating agreement is also known as "regulations" or the "limited liability company agreement" in some jurisdictions.

55. See e.g., Thomas A. Armbruster, Inc. v. Barron, 491 A.2d 882 (Pa. Super. Ct. 1985).

56. See Re-RULPA $\S 303 \mathrm{cmt}$; David W. Leebron, Limited Liability, Tort Victims, and Creditors, 91 Colum. L. Rev. 1565, 1625-26 (1991).

57. For example, a stockholder may be liable for torts of a corporation committed by persons under the shareholder's supervision or control. See Restatement (3d) Agency $\$ 7.05$.

58. See Rev. Unif. Partn. Act $\S 306 \mathrm{cmt}$.

59. Rev. Unif. Partn. Act $\$ 306(\mathrm{c})$.

60. Unif. LP Act $\S 7$ (1916).

61. RULPA $\S 303(\mathrm{~b})$. Re-RULPA $\S 303$ provides that a limited partner is not liable for the partner ship's obligations even if the limited partner participates in the management and control of the LP.

62. In addition, the person alleging liability must have reasonably believed, based on the limited partner's conduct, that the limited partner is a general partner. Rev. Unif. LP Act $\$ 303(a)$.

63. See Robert B. Thompson, Piercing the Corporate Veil: An Empirical Study, 76 Cornell L. Rev. 1036,1401 (1991).

64. See generally id. at 1063-74 (conducting an empirical study of approximately 1,600 piercing the corporate veil cases and analyzing the rationale used by courts for piercing or not piercing the corporate veil).

65. See generally Stephen B. Presser, Piercing the Corporate Veil (4th ed., Clark Boardman Callaghan 1991), detailing and analyzing the piercing the corporate veil doctrine.

66. See e.g., Kaycee Land \& Livestock v. Flabive, 46 P. 3d 323, 328 (Wyo. 2002) ("We can discern no reason, in either law or policy, to treat LLCs differently than we treat corporations. If the members and officers of an LLC fail to treat it as a separate entity as contemplated by statute, they should not enjoy immunity from individual liability for the LLC's acts that cause damage to third parties."). Contra Unif. LLC Act $\S 303(\mathrm{~b})$ (providing "that the failure of [an LLC] to observe the usual company formalities 
or requirements relating to the exercise of its company powers or management of its business is not a ground for imposing personal liability on the members or managers for liabilities of the company.").

67. See Rev. Unif. Partn. Act $\$ 401(f)$.

68. $I d$. at $\S 401(\mathrm{j})$.

69. See id. at $\S 103(\mathrm{a})$.

70. See RULPA $\S 403($ a); Re-RULPA $\S 402$. Re-RULPA would allow a limited partner to participate in the management or control of the LP without losing the shield of limited liability. Re-RULPA $\S 303$. However, a limited partner does not have the authority to act for or bind the LP. Re-RULPA $\S 302$.

71. RULPA $\S 303(b)(6)$.

72. $I d$.

73. Model Bus. Corp. Act $\$ \S 7.28,8.01(\mathrm{~b})$.

74. $I d$. at $\$ 8.41$.

75. $I d$. at $\S \S 10.03,10.20,11.04,12.01,14.02$.

76. Unif. LLC Act $\$ \S 103(a), 404$.

77. $I d$. at $\S 404(\mathrm{a})$.

78. $I d$. at $\$ 404(\mathrm{~b})$.

79. "Managers" refers to the directors and officers of a corporation, the general partners of an LP, and the managers of a manager-managed LLC.

80. Typically, owners of a business association, such as shareholders in a corporation, limited partners in an LP, and members in manager-managed LLC do not owe fiduciary duties to their co-owners or to the organization itself. See e.g., Schuur v. Berry, 281 N.W. 393 (Mich. 1938); Seitz v. Frey, 188 N.W. 266 (Minn. 1922). In some cases, owners with a controlling interest in the organization have been held to owe a duty to the minority owners. See e.g., Jacobson v. Yaschik, 155 S.E.2d 601 (S.C. 1967); Dauson v. Nat'l Life Ins. Co. of U.S., 157 N.W. 929 (Iowa 1916).

81. Model Bus. Corp. Act $\$ \S 8.30,8.42(a)$; Rev. Unif. Partn. Act $\S$ 404; RULPA $\S 403(a)$; Re-RULPA $\S 408$; Unif. LLC Act $\S 409$.

82. See e.g., ALI Principles Corp. Gov. $\$ 401(a)$, providing that directors and officers are required to perform their duties "with the care that an ordinary prudent person would reasonably be expected to exercise in a like position and in similar circumstances." But see Model Bus. Corp. Act $\S 8.30$, which rejects a prudent person standard and requires directors and officers to discharge their duties "with the care that a person in a like position would reasonably believe appropriate under the circumstances." A general partner's duty of care is limited to refraining from engaging in grossly negligent or reckless conduct, intentional misconduct, or knowing violations of the law. Rev. Unif. Partn. Act $\S$ 404(c); Re-RULPA $\S$ $408(\mathrm{c})$.

83. ALI Principles Corp. Gov. $\$$ 401(c); Model Bus. Corp. Act $\$ 8.31(a)$.

84. ALI Principles Corp. Gov. $\S$ 401(c).

85. Model Bus. Corp. Act $\$ 8.30$.

86. See ALI Principles Corp. Gov. $\$$ 401(a); RULPA $\S 404$; Re-RULPA $\S 408(b)$.

87. Harold Marsh Jr., Are Directors Tmustees? Conflicts of Interest and Corporate Morality, 22 Bus. Law. 35, 36 (1966).

88. See Model Bus. Corp. Act $\S 8.61$.

89. See Model Bus. Corp. Act $\S \S 8.61,8.62$.

90. See Broz v. Cellular Info. Sys., Inc., 673 A.2d 148, 154-55 (Del. 1996).

91. See Pat K. Chew, Competing Interests in the Corporate Opportunity Doctrine, 67 N.C. L. Rev. $435,455-91$ (1989), analyzing the various tests applied by courts to determine corporate opportunities.

92. See I.R.C. $\$ 11$.

93. See I.R.C. $\$ 301$.

94. I.R.C. $\S 701$.

95. See IRS Form 1065 and Schedule K-1.

96. I.R.C. $\$ 702$

97. I.R.C. $\S 731(\mathrm{a})$.

98. I.R.C. $\$ \S 1361$ et seq.

99. I.R.C. $\S \S 1363(\mathrm{a}), 1366,1368(\mathrm{~b})$

100. I.R.C. $\$ 1361(\mathrm{~b})(1)$. The $\mathrm{S}$ corporation election must be made by all of the stockholders and must be filed with the Internal Revenue Service within two and one-half months from the date of the corporation's incorporation if the election is to be effective as of the date the corporation is formed, or prior to two and one-half months after the beginning of the tax year in which the election is to take 
effect if the election is to be effective after the date of incorporation. I.R.C. $\$ 1362$. If the election is made effective after the corporation's date of incorporation, then pre-election corporate profits distributed to the stockholders after the effective date of the election are taxed as dividend income to the stockholders. I.R.C. $\$ 1368(\mathrm{c})$.

101. Treas. Reg. $\$ \S 301.7701-1-3$.

102. Treas. Reg. $\$ 301.7701-3(a)$.

103. $I d$.

104. Id

105. For the reading assignments, instructors may want to make electronic copies of necessary materials and set up an electronic reserve for students to access themselves, or make hard copies to use as handouts for students.

106. Infra "Part III."

107. The SIC is a taxonomy the U.S. government created in 1937 to organize businesses into specific industries. For example, any business classified in the forestry industry has the SIC code 0800. All SIC codes are four digits in length. The SIC system of classification is slowly being replaced by the North American Industry Classification System. See United States Department of Labor Occupational Safety $E$ Health Administration, http://www.osha.gov/pls/imis/sicsearch.html (last updated April 17, 2009).

108. This taxonomy is a six-digit classification scheme developed by the Office of Management and Budget to classify businesses into specific industries. This taxonomy was created in 1997 to create more congruent industrial definitions with Mexican and Canadian industries. A business classified in the Timber Tract Operations for example would have the NAICS number 113110. See United States Census Bureau, http://www.census.gov/eos/www/naics/ (last updated April 16, 2009).

109. This form guide is not to be used as a treatise. 